Spirits of Protestantism 


\section{THE ANTHROPOLOGY OF CHRISTIANITY}

Edited by Joel Robbins

I. Christian Moderns: Freedom and Fetish in the Mission Encounter, by Webb Keane

2. A Problem of Presence: Beyond Scripture in an African Church, by Matthew Engelke

3. Reason to Believe: Cultural Agency in Latin American Evangelicalism, by David Smilde

4. Chanting Down the New Jerusalem: Calypso, Christianity, and Capitalism in the Caribbean, by Francio Guadeloupe

5. In God's Image: The Metaculture of Fijian Christianity, by Matt Tomlinson

6. Converting Words: Maya in the Age of the Cross, by William F. Hanks

7. City of God: Christian Citizenship in Postwar Guatemala, by Kevin O'Neill

8. Death in a Church of Life: Moral Passion during Botswana's Time of AIDS, by Frederick Klaits

9. Eastern Christians in Anthropological Perspective, edited by Chris Hann and Hermann Goltz

Io. Studying Global Pentecostalism: Theories and Methods, by Allan Anderson, Michael Bergunder, Andre Droogers, and Cornelis van der Laan

II. Holy Hustlers, Schism, and Prophecy: Apostolic Reformation in Botswana, by Richard Werbner

I2. Moral Ambition: Mobilization and Social Outreach in Evangelical Megachurches, by Omri Elisha

I3. Spirits of Protestantism: Medicine, Healing, and Liberal Christianity, by Pamela E. Klassen 


\section{Spirits of Protestantism}

Medicine, Healing, and Liberal Christianity

\section{Pamela E. Klassen}

\section{甲}

UNIVERSITY OF CALIFORNIA PRESS

Berkeley • Los Angeles • London 
University of California Press, one of the most distinguished university presses in the United States, enriches lives around the world by advancing scholarship in the humanities, social sciences, and natural sciences. Its activities are supported by the UC Press Foundation and by philanthropic contributions from individuals and institutions. For more information, visit www.ucpress.edu.

University of California Press

Berkeley and Los Angeles, California

University of California Press, Ltd.

London, England

(C) 20I I by The Regents of the University of California

Library of Congress Cataloging-in-Publication Data

Klassen, Pamela E. (Pamela Edith), I967-

Spirits of Protestantism : medicine, healing, and

liberal Christianity / Pamela E. Klassen.

p. cm. - (Anthropology of Christianity ; I3)

Includes bibliographical references and index.

ISBN 978-0-520-24428-3 (hardcover : alk. paper) 978-0-520-27099-2 (paperback : alk. paper)

I. Healing-Religious aspects-Protestant

churches. 2. Protestantism-North America-

History. 3. Protestant churches-North America-

History. 4. Liberalism (Religion)—North America-

History. I. Title. II. Title: Medicine, healing, and

liberal Christianity.

BX48I7.K53 20II

$234^{\prime} \cdot \mathrm{I} 3 \mathrm{I}-\mathrm{dc} 22$

2010053382

Manufactured in the United States of America

$\begin{array}{llllllllll}20 & \text { I9 } & \text { I8 } 8 & \text { I7 } & \text { I6 } & \text { I5 } & \text { I4 } & \text { I3 } & \text { I2 } & \text { II }\end{array}$

IO $\quad 9 \begin{array}{lllllllll} & 8 & 7 & 6 & 5 & 4 & 3 & 2 & \text { I }\end{array}$

This book is printed on 5 \#\# Enterprise Cream, a $30 \%$ post consumer waste, recycled, de- inked fiber and processed chlorine free. It is acid-free, and meets all ANSI/NISO (z 39.48) requirements. 
For John 
